\title{
Efek Ketergantungan Remaja K-Popers terhadap Media Sosial di Kota Palu
}

\author{
Muhammad Khairil, Muhammad Isa Yusaputra, Nikmatusholeha
}

\author{
Fakultas Ilmu Sosial dan Ilmu Politik Universitas Tadulako \\ E-mail:muh_khairil02@yahoo.com,muhammadisa@untad.ac.id,nikmatusholeha@gmail. \\ com
}

\begin{abstract}
Korean culture was introduced in Indonesia since early 2000s through dramas, movies and musics. However, the Korean fever lasts about a decade. During that period, this commodity became better known as Korean Pop or K-Pop where teenagers who became the biggest consumers of this commodity known as K-Popers. K-Popers can not be separated from the technology development and the use of social media. This study is carried out using three aspects (frequency, duration and attention) of media exposure theory. The purpose of this study is to understand the effect of K-Pop information access on the teenager's social media dependency. This study is utilizing explanatory quantitative approach based on survey to 71 10th grade students of Unified Model High School of Madani Palu. Obtained data are analyzed using linear regression method. The results of the study shows that the effect of the frequency, duration and attention aspects in the population's access to K-Pop informations to the teenager's social media dependency of Palu City is at 77,1\%. Thus, it is concluded that there is a direct effect on K-Pop information access to the teenager's social media dependency. The substance provided by this study offers new point of view on the educational approach of social media usage in Palu City to improve the self-control and selective behaviour of social media usage.
\end{abstract}

Keywords: Teenagers, Effect, Dependency, K-Pop, Social Media

\begin{abstract}
Abstrak
Sejak tahun 2000, budaya Korea masuk ke Indonesia lewat jalur hiburan seperti drama, film, dan musik. Demam Korea baru berlangsung sekitar satu dekade. Selama periode itu, komoditas ini kemudian lebih dikenal dengan istilah Korean Pop atau K-Pop dan remaja menjadi konsumen terbesar dari komoditas ini yang lebih dikenal dengan istilah K-Popers. Remaja sebagai konsumen terbesar komoditas K-Pop, tidak dapat dipisahkan dengan perkembangan teknologi dan penggunaan media sosial di era milenial. Penelitian ini menggunakan teori terpaan media dengan melihat tiga aspek yaitu frekuensi, durasi dan atensi. Penelitian ini bertujuan untuk mengetahui pengaruh antara akses informasi K-Pop terhadap ketergantungan penggunaan media sosial di kalangan remaja. Penelitian dilakukan dengan metode eksplanatif kuantitatif dengan berdasar pada survey pada 71 siswa kelas 10 SMA Negeri Model Terpadu Madani Palu. Teknik analisis data pada penelitian ini menggunakan regresi linear berganda. Hasil penelitian menunjukkan bahwa teori teruji pada populasi ini dengan presentase pengaruh frekuensi, durasi dan atensi dalam mengakses informasi K-Pop terhadap tingkat ketergantungan penggunaan media sosial remaja di Kota Palu yakni sebesar 77,1\%. Terdapat pengaruh antara akses informasi K-Pop terhadap tingkat ketergantungan penggunaan media sosial pada remaja. Substansi penelitian ini mengusulkan kebijakan baru tentang pendekatan edukatif terkait pemanfaatan media sosial di Kota Palu sehingga lebih selektif dan mampu mengontrol diri dalam penggunaan media sosial.
\end{abstract}

Kata kunci : Efek, K-Pop, Ketergantungan, Media Sosial, Remaja

\section{Pendahuluan}

Kecintaan penggemar terhadap idolanya membuat apapun berita terbaru tentang idola yang disebarkan di media sosial akan selalu dipantau kapan saja tanpa mengenal waktu.
Pengemar K-Pop sering menghabiskan waktunya berjam-jam di depan komputer ataupun ponsel pintar yang dimiliki hanya untuk mencari, berbagi, dan berdiskusi tentang idola yang menjadi kesenangan, 
hingga ke perilaku obsesif yang berlebihan yaitu stalking (menguntit) apa saja terkait idola penggemar K-Pop.

Tidak dapat dipungkiri keberadaan K-Pop memberi efek konsumtif kepada para K-Popers. Sehingga penggemar rela menghabiskan waktu berjamjam hanya untuk sekedar mencari tahu informasi seputar K-Pop. Penelitian yang dilakukan oleh Ardia (Ardia, 2014: 12-18) tentang drama korea dan budaya popular menjelaskan bahwa kondisi ini merupakan dampak dari strategi komoditas produsen budaya K-Pop. Menurutnya Komoditas mengondisikan masyarakat sedemikian rupa dengan media budaya pop dan budaya massa agar membentuk pola perilaku yang konsumtif dan itu akan menguntungkan bagi kaum komoditas.

Perilaku konsumtif yang dilakukan peserta didik penggemar K-Pop tidak hanya menjadi pemenuhan hasrat atau keinginan, tetapi menjadi sebuah konsumsi tanda yang berkembang seiring dengan semakin banyak aktivitas yang dilakukan sebagai penggemar K-Pop (Wulandari, 2017). Dampak lain yang dialami K-Popers adalah perubahan konsep diri. Sobur (Sobur, dkk., 2018: 414422) menemukan tiga transformasi konsep diri K-Popers, transformasi konsep diri maskulin menjadi feminin; (2) transformasi konsep diri introvert menjadi ekstrovert; dan (3) transformasi dari konsep diri yang berpikiran tertutup menjadi pikiran terbuka yang menghargai pendapat orang lain.

Hasil survei yang dilakukan oleh kumparan.com, 56\% penggemar K-Pop menghabiskan waktu 1-5 jam memantau media sosial untuk mencari tahu segala informasi tentang idola tersebut. Sebanyak $28 \%$ penggemar bahkan menghabiskan 6 jam lebih di jagat maya untuk melihat berbagai aktivitas sang idola (Kumparan, 2017). Komunikasi di media sosial tidak dibatasi oleh jarak, waktu, dan ruang (Watie, 2011: 69-75)

Teknologi informasi dan komunikasi berkembang pesat, itu mencerminkan perilaku sosial orang dalam kehidupan dunia maya (Khairil, 2018: 158-172). Dunia maya atau dalam hal ini media sosial merupakan hal yang tidak bisa dipisahkan dari kehidupan masyarakat terutama remsaja di era milenial ini. Berkembangnya media sosial memberikan dampak baik positif maupun negatif bagi penggunanya (Juwita dkk., 2015: 17-24). Menurut Doni (2017: 15-23) penggunaan media sosial membawa begitu banyak kemudahan bagi penggunanya melalui segala fasilitas yang disediakan oleh media sosial, tetapi dibalik kemudahan tersebut kehadiran media sosial juga membawa sisi buruk bagi perilaku penggunannya.

Eliani (Eliani, dkk., 2018: 59-72) menyebutkan K-Popers sebagai Fans-idola K-Pop, menurut hasil temuanya fans-idola K-Pop dengan fanatisme yang tinggi akan memiliki perilaku agresif verbal yang tinggi, jika tidak penggemar-idola K-Pop yang memiliki fanatisme rendah akan memiliki perilaku agresif verbal yang rendah. Fanatisme menurut Widarti (2016: 1218) dalam bisa terpisah menjadi dua, yakn fanatisme yang masih bisa ditolerir dalam bingkai budaya lokal serta fanatisme yang 
tidak sesuai dengan budaya lokal. Fashion yang menutup aurat dan anggun, elegan serta menarik bisa dikategorikan dalam fanatisme golongan pertama

Remaja sebagai subjek dalam penelitian ini merupakan pengguna media sosial paling aktif. Supratman (2018: 47-60) mengistilahkan remaja pengguna media sosial di era milenial sebagai digital native. Hasil penelitian tersebut menyimpulkan bahwa digital native mampu menjadi warga net yang bijak ketika setelah melakukan adaptasi dan evaluasi terhadap pengalamanpengalaman dalam bersosial media secara mendalam.

Instagram bisa menjadi alat efektif pembentuk konstruksi sosial, sekaligus pembentuk wujud kuasa kebenaran dalam realitas sosial, Instagram sanggup membuat ruang kendali untuk mewujudkan keseragaman norma-norma kehidupan (Kertamukti dkk., 2018: 231-246).

Penggunaan media sosial saat ini juga menimbulkan efek berlebihan yang bisa menjadi masalah serius jika tidak teratasi secepatnya. Ada beberapa perilaku penggunaan media sosial yang harus diperhatikan, seperti selfie, cyber bullying, belanja online, personalisasi pengguna, dan budaya bersama (Mulawarman \& Nurfitri, 2017: 36-44).

Yulie Ismawaty Syah (Syah, 2018: 93105) dalam jurnalnya menyebutkan bahwa reaksi kaum muda perempuan terhadap K-Pop dapat diketahui melalui tiga cara, yakni tanda (semiotic productivity), antusiasme (enunciative productivity), dan textual productivity. Kaum muda merepresentasikan budaya penggemar K-Pop dengan cara peniruan dan imitasi. Kemunculan K-Pop yang fenomenal tidak lepas dari peran media masa berbuntut pada adanya penggemar yang sangat mengidolakan K-Pop dan menjadikan K-Pop sebagai identitas sosialnya. Penggemar dapat dikatakan sebagai pengikut yang sangat antusias terhadap apa saja yang dilakukan oleh sang idola, sehingga selalu merepresentasikan kembali apa yang telah disaksikan dari sang idola pada dikehidupan sosial .

Penggemar K-Pop seperti boyband misalnya, akan merepresentasikan bagaimana perilaku member boyband yang menjadi idola mereka, dan menggunakan bahasa-bahasa baik verbal maupun nonverbal yang diketahui oleh sesama penggemar. Hal ini dijelaskan oleh Supratman \& Rafiqi (2016:1-9), dalam penelitian mengenai kajian etnografi komunikasi pada gaya berkomunikasi komunitas Hansamo Modern Dance Boys di kota Bandung, menemukan bahwa terdapat gaya komunikasi verbal yang unik pada komunitas ini dimana mereka menggunakan bahasa pangggilan serta ungkapan bahasa korea dalam komunitas mereka saja. Selain itu, K-Popers menggunakan gaya komunikasi nonverbal yang berfungsi sebagai simbol kekompakan, pengikat dengan komunitas, dan identitas pembeda dengan komunitas pecinta musik korea lainnya.

Fenomena Korean Wave yang muncul melalui media informasi diketahui telah mempengaruhi semua kalangan, khususnya remaja. Umumnya Penggemar K-Pop 
adalah remaja. Survei yang dilakukan blog. jakpat.net pada tahun 2016, sebanyak 793 responden adalah penggemar K-Pop, dimana 42\% berada di umur 16-19 tahun dan 20-25 tahun menempati 35\% (Jakpat.net, 2016).

Hasil penelitian Etikasari (Etikasari, 2018: 190-202) mengungkapkan bahwa subjek penelitian yang merupakan K-Popers melakukan kegiatan mencari berita mengenai idola, download video dan lagu, menonton drama Korea, dan sebagainya. Etikasari menambahkan bahwa K-Popers memiliki kesulitan dalam mengendalikan perilaku dan emosi ketika ada seseorang yang mengejek sang idola; K-popers mampu mengolah informasi yang didapat tentang idola dengan bijak; dan bahwa K-Popers lebih mementingkan K-Pop dibandingkan dengan urusan lain. Subjek juga bertindak tidak disiplin dan mengabaikan keselamatan ketika menghadiri acara K-Pop hingga larut malam.

Rokeach dan DeFleur(Littlejohn\&Foss, 2011: 428) menjelaskan teori ketergantungan media memiliki asumsi bahwa seseorang bergantung pada media untuk memenuhi kebutuhan tertentu dan mencapai tujuan tertentu. Teori ketergantungan media pertama kali diusulkan oleh Sandra BallRokeach dan Melvin DeFleur (Morissan, 2015) pada tahun 1975 yang mengemukakan gagasan mengenai teori ketergantungan. Teori tersebut membahas tentang kekuatan media massa dalam mempengaruhi khalayak audiensi karena adanya sifat ketergantungan audiensi terhadap media massa.

Memang tidak hanya remaja saja yang terkena demam K-Pop, bahkan orang tua zaman sekarang juga tidak luput dari fenomena ini, tetapi yang menjadi pusat perhatian dari fenomena ini adalah para remaja. Usia remaja merupakan usia dimana seseorang sedang dalam proses pencarian jati diri sehingga mudah dipengaruhi. Selain itu keberadaan penggemar K-Pop di usia remaja lebih nampak terlihat di lingkungan masyarakat Indonesia saat ini. Di Kota Palu sendiri, mayoritas remaja penggemar K-Pop merupakan siswa-siswi SMA. Kemudahan akses media sosial juga dapat mengukuhkan norma-norma budaya dengan informasi-informasi yang disampaikannya sesuai dengan kebutuhan individu. Fenomena inilah yang dialami oleh para K-Popers, terutama K-Popers pada SMA Negeri Model Terpadu Madani Palu, yang telah menjadikan media sosial sebagai medium untuk dapat mengakses berbagai perkembangan informasi dalam jaringan media sosial K-Popers.

\section{Metode Penelitian}

Penelitian ini menggunakan penelitian eksplanasi untuk menguji hipetesis-hipotesis adanya hubungan sebab akibat antara gejala atau variabel yang diteliti (Saifuddin dkk., 2018: 30). Dasar dari penelitian ini adalah mengacu pada metode penelitian survei.

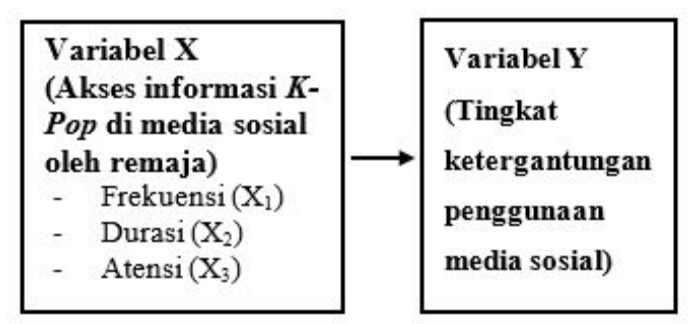

Bagan 1 Kerangka Variabel Penelitian Berdasarkan Teori Terpaan Media Sumber: Rakhmat, 2012 
Variabel penyebab atau pengaruh pada penelitian ini adalah akses informasi K-Pop oleh remaja dan variabel tergantungnya adalah intensitas penggunaan media sosial.

Penelitian ini dilakukan di SMA Negeri Model Terpadu Madani Palu, dimana lokasi ini menjadi tempat responden bersekolah. Populasi dalam penelitian ini adalah siswa SMA Negeri Model Terpadu Madani Palu. Peneliti memilih siswa kelas 10 sebagai populasi dengan total siswa berjumlah 240 orang.

Jumlah sampel pada penelitian ini ditentukan menggunakan rumus besaran sampel Slovin (Yusuf, 2014: 170) sebagai berikut:

$$
n=\frac{N}{1+N(e)^{2}}
$$

$\mathrm{n}$ : Jumlah sampel yang dicari

$\mathrm{N}$ : Jumlah Populasi

e : Nilai error sebesar $10 \%$

berdasarkan rumus di atas maka sampel dapat dihitung sebagai berikut:

$$
n=\frac{240}{240(0,1)^{2}+1}=\frac{240}{240(0,01)+1}=\frac{240}{3,40}=70,58
$$

Hasilnya adalah 70,58 dibulatkan menjadi 71 orang.

Berdasarkan teknik yang dijelaskan, peneliti menyebarkan kuesioner kepada 71 responden yang dinyatakan memenuhi kriteria yang sudah ditentukan. Sehingga didapatkan data yang sesuai untuk penelitian ini. Peneliti menentukan kriteria sampel sebagai berikut: (1) Penggemar K-Pop; (2) menggunakan media sosial dalam mengakses informasi K-Pop.

Analisis data yang digunakan dalam penelitian ini adalah persamaan regresi linear berganda. Alasan pemilihan metode analisis ini karena dapat mengukur pengaruh variabel independen terhadap variabel dependen yang diteliti secara menyeluruh maupun secara individu, maka dapat diformulasikan dengan menggunakan rumus regresi linear berganda sebagai berikut (Kurniawan \& Yuniarto, 2016: 97):

$$
Y=a+b_{1} X_{1}+b_{2} X_{2}+b_{3} X_{3}+e
$$

Dimana:

$\mathrm{Y}=$ Ketergantungan Penggunaan Media Sosial

$\alpha=$ Nilai interesept (konstanta)

$\mathrm{b}=$ Koefisien regresi

$\mathrm{X}_{1}=$ Frekuensi Akses informasi K-Pop di Media Sosial

$\mathrm{X}_{2}=$ Durasi Akses informasi K-Pop di Media Sosial

$\mathrm{X}_{3}=$ Atensi Akses informasi K-Pop di Media Sosial

$e=$ Kesalahan pengganggu (error)

Membuktikan hipotesis digunakan uji statistik dengan menggunakan program program SPSS (Statistical Package For Social Science) for windows version 25 dengan memasukan variabel-variabel $\mathrm{Y}, \mathrm{X}_{1}$, $\mathrm{X}_{2}, \mathrm{X}_{3}$ selanjutnya dilakukan pula uji $\mathrm{F}$ dan uji $\mathrm{T}$.

Uji F digunakan untuk mengetahui apakah seluruh variabel independen (X) secara silmutan (bersama-sama) mempunyai pengaruh yang signifikan terhadap variabel dependen (Y) untuk mengetahui apakah variabel independen berpengaruh signifikan terhadap variabel dependen dilakukan dengan perbandingan antara $\mathrm{F}_{\text {hitung }}$ dan $\mathrm{F}_{\text {tabel }}$ pada tingkat kepercayaan $90 \%(\alpha=0,1)$ 
dengan pedoman sebagai berikut: (1) apabila $\mathrm{F}_{\text {hitung }}>\mathrm{F}_{\text {tabel }}$ dan $\mathrm{p}<0,1$, maka terbukti semua variabel bebas yang diamati secara bersamaan berpengaruh secara signifikan terhadap variabel terikat; (2) apabila $F_{\text {hitung }}$ $<\mathrm{F}_{\text {tabel }}$ dan $\mathrm{p}>0.1$, maka terbukti semua variabel bebas yang diamati secara bersamasama (simultan) tidak berpengaruh signifikan terhadap variabel terikat.

Nilai $F_{\text {hitung }}$ diperoleh dari hasil perhitungan program SPSS (Statistical Package For Social Science) for windows version 25 dalam tabel ANOVA (Analysis Of Variance) sedangkan $\mathrm{F}_{\text {hitung }}$ diperoleh dengan melihat $\mathrm{F}$ (sesuai dengan tingkat kepercayaan yang ditentukan).

Dari tabel ANOVA (hasil uji SPSS) juga diperoleh koefesien determinasi $\left(\mathrm{R}^{2}\right)$ berada diantara 1 kurang dari $\mathrm{R}^{2}$ kurang dari 0 mendekati 1, maka model regresi linear berganda dinilai sangat kuat.

Uji $\mathrm{t}$ dilakukan untuk mengetahui apakah masing-masing variabel independen mempunyai pengaruh yang signifikan terhadap variabel dependen. Adapun caranya yaitu dengan melakukan perbandingan:

$\mathrm{t}_{\text {hitung }}>\mathrm{t}_{\text {tabel }}$ pada tingkat kepercayaan 95\% dan ketidakpercayaan 5\%

$t_{\text {hitung }}<t_{\text {tabel }},(\alpha=0,1)$ dengan pedoman sebagai berikut: (1) apabila $t_{\text {hitung }}>t_{\text {tabel }}$ dan $\mathrm{p}<0,05$, maka variabel independen yang diamati secara parsial berpengaruh signifikan terhadap variabel dependen; (2) apabila $\mathrm{t}_{\text {hitung }}<\mathrm{t}_{\text {tabel }}$ dan $\mathrm{p}>0,05$, maka variabel independen yang diamati secara parsial tidak berpengaruh signifikan terhadap variabel dependen.

Nilai $t_{\text {hitung }}$ diperoleh dari hasil perhitungan program SPSS (Statistical Package For Social Science) for windows version 25 dalam tabel ANOVA (Analysis Of Variance), sedangkan $t_{\text {tabel }}$ diperoleh dengan cara df (degree of freedom). Selanjutnya koeefisien penentu atau koefesien determinasi parsial, yang artinya penyebab perubahan dari variabel $\mathrm{Y}$ yang datangnya dari variabel $\mathrm{X}_{1}, \mathrm{X}_{2}, \mathrm{X}_{3}$ sebesar kuadrat koefesien korelasinnya.

\section{Hasil Penelitian Dan Pembahasan}

Tabel 1 menunjukkan bahwa hubungan antara indikator $\mathrm{X}_{1}$ frekuensi dalam mengakses informasi K-Pop terhadap tingkat ketergantungan penggunaan media sosial (Y) positif yakni sbesar 0.789 , sedangkan tanda ** dapat diartikan korelasi signifikan pada level 0.05 , sehingga dapat dinyatakan bahwa ada hubungan positif antara frekuensi dan tingkat ketergantungann penggunaan media sosial sebesar 0.789 . Artinya semakin sering responden mengakses informasi K-Pop maka semakin tinggi tingkat ketergantungan penggunaan media sosial. selain itu nilai

Tabel 1 Korelasi Product Moment Hubungan Frekuensi terhadap Tingkat Ketergantungan Penggunaan Media Sosial Remaja

\begin{tabular}{|c|c|c|c|}
\hline \multicolumn{4}{|c|}{ Correlations } \\
\hline & & Frekuensi & Tingkat \\
\hline \multirow[t]{4}{*}{ Frekuensi } & Pearson & 1 & $.789 * *$ \\
\hline & Correlation & & \\
\hline & Sig. (2-tailed) & & .000 \\
\hline & $\mathrm{N}$ & 71 & 71 \\
\hline \multirow{4}{*}{$\begin{array}{l}\text { Tingkat } \\
\text { Ketergan- } \\
\text { tungan }\end{array}$} & Pearson & $.789 * *$ & 1 \\
\hline & Correlation & & \\
\hline & Sig. (2-tailed) & .000 & \\
\hline & $\mathrm{N}$ & 71 & 71 \\
\hline
\end{tabular}

**. Correlation is significant at the 0.01 level (2-tailed).

Sumber: Hasil Uji Statistik Menggunakan IBM SPSS 25, 2018 
0.783 merupakan nilai keeratan yang kuat karena berada di kisaran $0.70-0.89$.

Tabel 2 menjunjukkan bahwa hubungan antara indikator $\mathrm{X}_{2}$ Durasi dalam mengakses informasi K-Pop terhadap tingkat ketergantungan penggunaan media sosial (Y) positif yakni sebesar 0.626. Tanda ** dapat diartikan korelasi signifikan pada level 0.05 , sehingga dapat dinyatakan bahwa ada hubungan positif antara durasi dan tingkat ketergantungann penggunaan media sosial sebesar 0.626. Artinya semakin sering responden mengakses informasi K-Pop maka semakin tinggi tingkat ketergantungan penggunaan media sosial. Selain itu nilai 0.626 merupakan nilai keeratan yang sedang atau cukup karena berada di kisaran 0.40 -0.69 .

Tabel 3 menunjukkan bahwa hubungan antara indikator $\mathrm{X}_{3}$ atensi dalam mengakses informasi K-Pop terhadap tingkat ketergantungan penggunaan media sosial (Y) positif yakni sebesar 0.809 . Tanda ** dapat diartikan korelasi signifikan pada level

Tabel 2 Korelasi Product Moment Hubungan Durasi terhadap Tingkat Ketergantungan Penggunaan Media Sosial Remaja

\begin{tabular}{llrr}
\hline Correlations & Durasi & \multicolumn{2}{l}{ Tingkat } \\
& & & Ketergantungan \\
\hline Durasi & Pearson & 1 & $.626^{* *}$ \\
& Correlation & & .000 \\
& Sig. (2-tailed) & & 71 \\
& N & 71 & 1 \\
Tingkat & Pearson & $.626^{* *}$ & \\
Ketergan- & Correlation & & 71 \\
tungan & Sig. (2-tailed) & .000 & \\
& N & 71 & \\
\hline
\end{tabular}

**. Correlation is significant at the 0.01 level (2-tailed).

Sumber: Hasil Uji Statistik Menggunakan IBM SPSS 25, 2018
Tabel 3 Korelasi Product Moment Hubungan Atensi terhadap Tingkat Ketergantungan Penggunaan Media Sosial Remaja

\begin{tabular}{llrr}
\hline Correlations & & \\
\hline & & Atensi & \multicolumn{2}{l}{ Tingkat } \\
& & Ketergantungan \\
\hline Atensi & Pearson & 1 & $.809^{* *}$ \\
& Correlation & & .000 \\
& Sig. (2-tailed) & & 71 \\
& $\mathrm{~N}$ & 71 & 1 \\
Tingkat & Pearson & $.809^{* *}$ & \\
Ketergan- & Correlation & & \\
tungan & Sig. (2-tailed) & .000 & \\
& $\mathrm{~N}$ & 71 & \\
\hline$* *$. Correlation is significant at the 0.01 level & (2-tailed).
\end{tabular}

Sumber: Hasil Uji Statistik Menggunakan IBM SPSS 25, 2018

0.05 , sehingga dapat dinyatakan bahwa ada hubungan positif antara atensi dan tingkat ketergantungan penggunaan media sosial sebesar 0.809 .

Artinya semakin besar perhatian responden dalam mengakses informasi K-Pop maka semakin tinggi tingkat ketergantungan penggunaan media sosial. Selain itu nilai 0.809 merupakan nilai keeratan yang kuat karena berada di kisaran $0,70-0.89$.

Berdasarkan tabel 4, nilai koefisisen determinasi adalah sebesar 0.771 , dimana 0,771 adalah pengkuadratan dari koefisien korelasi atau $\mathrm{R}$, yaitu $0.878^{2}$. Besarnya angka koefisien determinasi $\mathrm{R}$ Square. Tabel 4 Koefisien Determinasi $\left(\mathrm{R}^{2}\right)$ Akses informasi K-Pop "Frekuensi, Durasi, Atensi"

\begin{tabular}{|c|c|c|c|c|}
\hline \multicolumn{5}{|c|}{ Model Summary } \\
\hline Model & $\mathrm{R}$ & R Square & $\begin{array}{l}\text { Adjusted R } \\
\text { Square }\end{array}$ & $\begin{array}{l}\text { Std. Error } \\
\text { of the } \\
\text { Estimate }\end{array}$ \\
\hline 1 & $.878^{\mathrm{a}}$ & .771 & .761 & 8.06148 \\
\hline
\end{tabular}

a. Predictors: (Constant), Atensi, Durasi, Frekuensi

Sumber: Hasil Uji Statistik Menggunakan IBM SPSS 25, 2018 
0,771 sama dengan 77,1\%. Angka tersebut menunjukkan pengaruh yang kuat dan nyata antara variabel bebas akses informasi (X) dan tingkat ketergantungan penggunaan media sosial pada remaja. Nilai R Square adalah 0.771 menunjukkan bahwa secara simultan variabel bebas akses informasi memberikan kontribusi sebesar 77,1\% terhadap variabel terikat tingkat ketergantungan penggunaan media sosial remaja. Sedangkan sisanya 22.9\% merupakan variabel lain yang tidak disertakan dalam penelitian ini

Uji $F$ digunakan untuk mengetahui seberapa jauh frekuensi $\left(\mathrm{X}_{1}\right)$, durasi $\left(\mathrm{X}_{2}\right)$, atensi $\left(\mathrm{X}_{3}\right)$, secara bersama-sama terhadap tingkat ketergantungan penggunaan media sosial remaja (Y). Untuk menjawab pertanyaan tersebut dapat di lihat melalui uji ANOVA yang tersaji pada tabel 5. Adapun kriteria pengujiannya adalah sebagai berikut: (1) Ho diterima jika $\mathrm{F}_{\text {hitung }}<\mathrm{F}_{\text {tabel }}$ pada $\alpha=$ $10 \%$; (2) Ha diterima jika $\mathrm{F}_{\text {hitung }}>\mathrm{F}_{\text {tabel }}$ pada $\alpha=10 \%$.

Berdasarkan tabel 5 hasil uji Anova, diperoleh nilai Fhitung sebesar $75.261>$ $\mathrm{F}_{\text {tabel }} 2.74$ dengan tingkat signifikasi lebih kecil dari Tarif nyata $(0.000<0.1)$, dengan demikian hasil ini bermakna bahwa secara simultan (bersama-sama) keseluruhan variabel independen X (frekuensi, durasi, atensi) berpengaruh signifikan terhadap variabel Y (Tingkat ketergantungan penggunaan media sosial).

Uji t digunakan untuk menguji hipotesis secara parsial (individu) yang bertujuan untuk mengetahui seberapa jauh pengaruh masing-masing variabel bebas terhadap variabel terikat secara sendiri-sendiri yaitu frekuensi $\left(\mathrm{X}_{1}\right)$, durasi $\left(\mathrm{X}_{2}\right)$, atensi $\left(\mathrm{X}_{3}\right)$, terhadap tingkat ketergantungan penggunaan media sosial remaja (Y).

McLuhan (Nimmo, 2011) menyatakan bahwa setiap media komunikasi mempunyai gramatika. Gramatika adalah aturan kerja yang erat hubungannya dengan gabungan indera (penglihatan, sentuhan, suara, penciuman, dan sebagainya) yang berkait dengan penggunaan media oleh seseorang. Setiap gramatika media dibiaskan untuk kepentingan indera tertentu karena orangorang menggunakan media tertentu,. Digunakan secara berlebihan mengandalkan indera yang berkaitan dengan media tersebut sehingga media merupakan perpanjangan

Tabel 5 Hasil Uji F Pengaruh Frekuensi (X1), Durasi (X2), Atensi (X3), terhadap tingkat ketergantungan penggunaan media sosial Remaja (Y)

\begin{tabular}{|c|c|c|c|c|c|c|}
\hline \multicolumn{7}{|c|}{ ANOVA $^{a}$} \\
\hline \multirow{4}{*}{1} & Model & Sum of Squares & df & Mean Square & $\mathrm{F}$ & Sig. \\
\hline & Regression & 14673.085 & 3 & 4891.028 & 75.261 & $.000^{\mathrm{b}}$ \\
\hline & Residual & 4354.155 & 67 & 64.987 & & \\
\hline & Total & 19027.239 & 70 & & & \\
\hline
\end{tabular}

a. Dependent Variable: Tingkat_Ketergantungan

b. Predictors: (Constant), Atensi, Durasi, Frekuensi

Sumber: Hasil Uji Statistik Menggunakan IBM SPSS 25, 2018 
Tabel 6 Hasil Uji t Pengaruh Akses Informasi K-Pop terhadap tingkat ketergantungan penggunaan media sosial Remaja

\begin{tabular}{|c|c|c|c|c|c|c|c|c|c|}
\hline \multicolumn{10}{|c|}{ Coefficients a } \\
\hline & \multirow[b]{2}{*}{ Model } & \multicolumn{2}{|c|}{$\begin{array}{l}\text { Unstandardized } \\
\text { Coefficients }\end{array}$} & \multirow{2}{*}{$\begin{array}{c}\text { Standardized } \\
\text { Coefficients } \\
\text { Beta }\end{array}$} & \multirow[b]{2}{*}{$\mathrm{t}$} & \multirow[b]{2}{*}{ Sig. } & \multicolumn{3}{|c|}{ Collerations } \\
\hline & & $\mathrm{B}$ & $\begin{array}{l}\text { Std. } \\
\text { Error }\end{array}$ & & & & Zero-order & Partial & Part \\
\hline \multirow{4}{*}{1} & (Constant) & 17.107 & 4.446 & & 3.848 & .000 & & & \\
\hline & Frekuensi & 2.815 & 609 & .410 & 4.619 & .000 & .789 & .491 & .270 \\
\hline & Durasi & .536 & .564 & .076 & .950 & .345 & .626 & .115 & .056 \\
\hline & Atensi & 4.647 & .753 & .494 & 6.169 & .000 & .809 & .602 & .361 \\
\hline
\end{tabular}

a. Dependent Variable: Tingkat_Ketergantungan

Sumber: Hasil Uji Statistik Menggunakan IBM SPSS 25, 2018

dari indera manusia, bicara sebagai perpanjangan indera untuk suara, cetakan merupakan perpanjangan dari indera untuk penglihatan dan media elektronik tertentu (misalnya televisi) adalah perpanjangan indera peraba.

Senada dengan apa yang disampaikan oleh McLuhan, Innis (Littlejohn \& Foss, 2011) memandang bahwa media komunikasi sebagai perpanjangan tangan dari pikiran manusia dan beranggapan bahwa kecenderungan utama dalam periode sejarah manapun adalah merupakan suatu pengaruh dari media yang berkuasa pada saat itu. Dengan kata lain, apa yang terjadi dan apa yang tampaknya penting dalam suatu periode sejarah ditentukan oleh media.

Ketergantungan suatu media merupakan timbul dari adanya terpaan media. Terpaan media adalah banyaknya informasi yang diperoleh melalui media, yang meliputi frekuensi, atensi dan durasi penggunaan pada setiap jenis media yang digunakan (Rakhmat, 2012). Terpaan merupakan intensitas keadaan khalayak dimana terkena pesan-pesan yang disebarkan oleh suatu media. Menurut Ardianto dkk. (2014:168) terpaan dapat diartikan sebagai kegiatan mendengar, melihat, membaca pesan-pesan media ataupun mempunyai pengalaman dan perhatian terhadap pesan tersebut yang dapat terjadi pada individu atau kelompok. Terpaan media berusaha mencari data khalayak tentang media baik jenis media, frekuensi penggunaan maupun durasi penggunaan. Penggunaan jenis media meliputi media audio, audio visual, media cetak, dan online. Untuk mengukur terpaan media dapat dilihat dari 3 faktor: yakni frekuensi, durasi dan atensi.

Dari hasil perhitungan diperoleh hasil sebagai berikut: (1) Nilai thitung frekuensi yaitu 4.619 lebih besar dari $t_{\text {tabel }}$ yaitu 2.292 (4.619> 2.2929). Sementara itu nilai koefisien determinasi parsial $\left(\mathrm{r}^{2}\right)$ adalah sebesar $\left(0.491^{2}\right)$ atau 0.241081 atau $24.1 \%$. Nilai ini memberikan makna secara parsial variabel durasi $\left(\mathrm{X}_{1}\right)$ berpengaruh secara signifikan terhadap ketergantungan penggunaan media sosial remaja; (2) Nilai $\mathrm{t}_{\text {hitung }}$ durasi 0.950 lebih kecil dari $\mathrm{t}_{\text {tabel }}$ yaitu $2.292(0.950<2.292)$ Dengan demikian 
nilai ini memberikan makna secara parsial variabel durasi $\left(\mathrm{X}_{2}\right)$ tidak berpengaruh secara signifikasn terhadap ketergantungan penggunaan media sosial remaja; (3) Nilai $\mathrm{t}_{\text {hitung }}$ atensi yaitu 6.169 lebih besar dari $\mathrm{t}_{\text {tabel }}$ yaitu $2.292(6.169>2.292)$. Sementara itu nilai koefisien determinasi parsial $\left(\mathrm{r}^{2}\right)$ adalah sebesar (0.6022) atau 36.2\%. Nilai ini memberikan makna secara parsial variabel atensi $\left(\mathrm{X}_{3}\right)$ berpengaruh signifikan terhadap ketergantungan penggunaan media sosial remaja.

\section{Simpulan}

Berdasarkan hasil penelitian maka disimpulkan bahwa ada dua faktor yang yang menentukan ketergantungan seseorang terhadap media. Pertama, Seseorang akan lebih bergantung pada media yang dapat memenuhi sejumlah kebutuhannya sekaligus dibandingkan dengan media yang hanya mampu memenuhi beberapa kebutuhan saja. Dalam penelitian ini, faktor pertama yang menentukan ketergantungan akan media adalah penggunaan media sosial yang dirasa memuaskan dalam memenuhi kebutuhan informasi K-Pop pada individu. Faktor kedua adalah stabilisasi sosial. Lingkungan sosial tidak mampu memberikan kebutuhan informasi yang individu inginkan sehingga K-Popers lebih memilih menggunakan media sosial demi pemenuhan kebutuhan informasinya. Hal ini disebabkan karena di lingkungan tempat tinggalnya, hanya idividu itu sendiri yang memiliki kegemaran akan Korean Pop. Tiga komponen yaitu audiens, sistem media dan sistem sosial saling berhubungan, meskipun sifat hubungan ini yang didapatkan setiap individu berbeda-beda.

Terdapat tiga komponen yang merupakan efek dari mengakses pesan yaitu kognitif, afektif, dan konatif semuanya berkaitan dan saling mempengaruhi satu sama lain. Dalam teori ketergantungan media menguatkan bahwa para remaja memiliki sikap ketergantungan terhadap media sosial dalam mengakses informasi K-Pop. Teori ini memperlihatkan bahwa individu bergantung pada media untuk pemenuhan kebutuhan atau untuk mencapai tujuannya tetapi mereka tidak bergantung pada banyak media. Mereka memilih media mana yang akan mereka gunakan untuk memenuhi keinginannya.

Hasil penelitian ini menunjukkan bahwa teori teruji pada populasi yang pengaruh akses informasi K-Pop memiliki hubungan yang positif serta signifikan terhadap tingkat keketergantungan penggunaan media sosial. Hasil penelitian menyatakan bahwa ada hubungan positif dan signifikan antara durasi, frekuensi, atensi dengan terhadap tingkat keketergantungan penggunaan media sosial.

Selanjutnya pada analisis regresi atau pengaruh secara simultan hasil penelitian menunjukkan bahwa terdapat pengaruh yang signifikan antara frekuensi, durasi, dan atensi secara bersama-sama terhadap tingkat keketergantungan penggunaan media sosial dengan kontribusi sebesar 59.4\% Secara individu, frekuensi $\left(\mathrm{X}_{1}\right)$ memiliki pengaruh yang signifikan terhadap $\mathrm{Y}$ dengan kontribusi sebesar $24.1 \%$. dan atensi $\left(\mathrm{X}_{3}\right)$ memiliki pengaruh signifikan terhadap $\mathrm{Y}$ dengan kontribusi sebesar 36.2\%. Durasi $\left(\mathrm{X}_{2}\right)$ tidak 
memiliki perilaku yang signifikan.

Hasil presentase pengaruh variabel $\mathrm{X}$ (Frekuensi, durasi, atensi) dalam mengakses informasi K-Pop terhadap variabel $\mathrm{Y}$ (tingkat ketergantungan penggunaan media sosial remaja di Kota Palu yakni sebesar $77 \%$. Dengan demikian pada hipotesis $\mathrm{Ha}$ diterima dan $\mathrm{H} 0$ ditolak. Berdasarkan hal tersebut dapat disimpulkan bahwa terdapat pengaruh antara akses informasi K-Pop terhadap tingkat ketergantungan penggunaan media sosial pada remaja.

Efek yang signifikan ketergantungan remaja usia sekolah terhadap penggunaan media sosial khususnya dalam mengakses informasi terkait dengan K-Pop menjadi fakta yang tak terelakan bahwa peran dan fungsi media sosial begitu besar dan menjadi kebutuhan sosial di era keterbukaan dan perkembangan teknologi infomasi. Eksploitasi terhadap informasi K-Pop melalui penggunaan media sosial telah menjadi komuditas informasi bagi para remaja khususnya remaja di usia sekolah.

Berdasarkan hasil ini, maka peneliti memberikan beberapa saran, yakni remaja perlu untuk memahami dampak postif maupun negatif dalam penggunaan media sosial, sehingga lebih bijak lagi dalam menggunakan media sosial. Media sosial bisa menjadi hiburan bagi penggunanya tetapi gunakan di waktu yang tepat sehingga tidak menjadi suatu hal yang negatif bagi diri remaja.

\section{Daftar Pustaka}

Ardia, V. (2014). DRAMA KOREA DAN BUDAYA POPULAR. LONTAR: Jurnal Ilmu Komunikasi, 2(3), 12-18. https:// doi.org/http://dx.doi.org/10.30656/ lontar.v2i3.337

Ardianto, E., Komala, L., \& Karlinah, S. (2014). Komunikasi Massa Suatu Pengantar. Bandung: Simbiosa Rekatama Media.

Doni, F. R. (2017). Perilaku Penggunaan Media Sosial Pada Kalangan Remaja. IJSE - Indonesian Journal on Software Engineering, 3(2), 15-23.

Eliani, J., Yuniardi, M. S., \& Masturah, A. N. (2018). Fanatisme dan Perilaku Agresif Verbal di Media Sosial pada Penggemar Idola K-Pop. Psikohumaniora: Jurnal Penelitian Psikologi, 3(1), 59-72. https:// doi.org/http://dx.doi.org/10.21580/pjpp. v3i1.2442

Etikasari, Y. (2018). Kontrol Diri Remaja Penggemar K-Pop (K-Popers). Jurnal Riset Mahasiswa Bimbingan Dan Konseling, 4(3), 190-202.

Jakpat.net. (2016). The Fandom for Idols - A Survey Report on Kpop Fans in Indonesia. Retrieved from https://blog.jakpat.net/ the-fandom-for-idols-a-survey-reporton-kpop-fans-in-indonesia/

Juwita, E. P., Budimansyah, D., \& Nurbayani, S. (2015). PERAN MEDIA SOSIAL TERHADAP GAYA HIDUP SISWA SMA NEGERI 5 BANDUNG. Jurnal Sosietas, 5(1), 17-24.

Kertamukti, R., Nugroho, H., \& Wahyono, S. B. (2018). Komunikasi Visual: Fantasi Tubuh Wanita Kelas Menengah di Instagram. Jurnal Kajian Komunikasi, 6(2), 231-246.

Khairil, M. (2018). Understanding The Perpetrators And Victims of Cyberbullying Through Facebook in The City of Palu. KOMUNIKA: Jurnal Dakwah Dan Komunikasi, 12(1), 158-172. https://doi.org/10.24090/ KOMUNIKA.V12I1.1646 
Kumparan. (2017). Fanatisme Fans K-Pop: Candu dan Bumbu Remaja. Retrieved from https://kumparan.com/@ kumparank-pop/fanatisme-fans-k-popcandu-dan-bumbu-remaja

Kurniawan, R., \& Yuniarto, B. (2016). Analisis Regresi: Dasar dan Penerapannya dengan R. Jakarta: Kencana.

Littlejohn, S. W., \& Foss, K. A. (2011). Theories of Human Communication 10ed (10th ed.). Long Grove: Waveland Press, Inc.

Morissan. (2015). Teori Komunikasi Individu Hingga Massa. Jakarta: Kencana.

Mulawarman, \& Nurfitri, A. D. (2017). Perilaku Pengguna Media Sosial beserta Implikasinya Ditinjau dari Perspektif Psikologi Sosial Terapan. Buletin Psikologi, 25(1), 36-44. https://doi. org/10.22146/buletinpsikologi.22759

Nimmo. (2011). Komunikasi Politik: Khalayak, Dan Efek: Terj. Jalaluddin Rakhmat. Bandung: Remaja Rosdakarya.

Rakhmat, J. (2012). Psikologi Komunikasi. Bandung: Rosdakarya.

Saifuddin, Ismail, M. S., \& Wekke, I. S. (2018). Strategi dan Teknik Penulisan Skripsi (1st ed.). Yogyakarta: Deepublish.

Sobur, A., Darmawan, F., Kusumalestari, R. R., Listiani, E., Ahmadi, D., \& Albana, M. A. (2018). The Meaning of K-Pop and Self-Concept Transformation of K-Pop Fans in Bandung. MIMBAR: Jurnal Sosial Dan Pembangunan, 34(2),
414-422. https://doi.org/https://doi. org/10.29313/mimbar.vol34iss2pp\%25p

Supratman, L. P. (2018). Penggunaan Media Sosial oleh Digital Native. Jurnal Ilmu Komunikasi, 15(1), 47-60.

Supratman, L. P., \& Rafiqi, A. (2016). Kajian Etnografi Komunikasi pada Gaya Berkomunikasi Komunitas Hansamo Modern Dance Boys di Kota Bandung. Jurnal Kajian Komunikasi, 4(1), 1-9. https://doi.org/https://doi.org/10.24198/ jkk.v4i1

Syah, Y. I. (2018). Representasi Budaya Kaum Muda Perempuan Sebagai Penggemar Korean Pop (Studi Pada Mahasiswi Ilmu Komunikasi Angkatan 2013). KINESIK, 5(1), 93-105. https://doi.org/10.22487/ kinesik.v5i1.10176

Watie, E. D. S. (2011). Komunikasi dan Media Sosial. The Messenger, 3(1), 69-75.

Widarti. (2016). Konformitas dan Fanatisme Remaja Kepada Korean Wave (Studi Kasus pada Komunitas Penggemar Grup Musik CN Blue). Jurnal Komunikasi, 7(2), 12-18. https://doi.org/10.31294/ jkom.v7i2.1486

Wulandari, S. (2017). PERILAKU KONSUMTIF PESERTA DIDIK PENGGEMAR K-POPDISMANEGERI 4 SURAKARTA. SOSIALITAS: Jurnal Ilmiah Pend. Sos Ant, 8(1).

Yusuf, A. M. (2014). Metode Penelitian Kuantitatif, Kualitatif \& Penelitian Gabungan. Jakarta: Kencana. 